\title{
Інструмент, порошки, пасти
}

UDC 621.9.025.7

\author{
Yang Xuefeng ${ }^{1, *}$, Deng Fuming ${ }^{1, * *}$, Deng Wenli ${ }^{1}$, \\ Xi Peiyao', Tan Chuxuan ${ }^{1}$, Lu Xuejun ${ }^{1,2}$ \\ ${ }^{1}$ Institute of Superhard Cutting Tool Materials, China University \\ of Mining and Technology (Beijing), Beijing, China \\ ${ }^{2}$ Beijng Dimengjingrui Science and Technology Co., \\ Ltd., Beijing, China \\ *381281866@qq.com \\ **dfm@cumtb.edu.cn
}

\section{Optimization of designing on cutter parameters of PCD saw blades by simulation analysis}

The cutter parameters of PCD circular saw blades play a decisive role in the wood cutting process, they directly affect the machining surface quality and tool life. Simulation analysis of the cutting stress and deformation of PCD wood circular saw blades with different cutter parameters is carried out using the finite element method. The results show that the maximum shear stress of the PCD saw blade in cutting process are all in a safety range with safety coefficient of about 3.5-4.0, and the maximum displacement of PCD saw blades are about 4.8-4.9 $\mu \mathrm{m}$ in the axial direction and about $10 \mu \mathrm{m}$ in radial and rotation directions. It was found that the best cutter parameters of the PCD circular saw blades are rake angle $\gamma=15^{\circ}$ and rear angle $\alpha=15^{\circ}$, in which the relative low stress of $58.9 \mathrm{MPa}$ and relative smaller displacement of can be achieved.

Keywords: polycrystalline diamond (PCD), wood circular saw, finite element analysis (ANSYS), cutter parameters.

\section{INTRODUCTION}

In order to maintain long-term sawtooth sharpness of the circular saw blade under high-speed and noncontinuous cutting conditions, the wood cutting tool materials have to possess such properties as high hardness and wear resistance, sufficient strength and toughness, and the sawtooth parameters of PCD circular saw blades should be designed rationally. Polycrystalline diamond (PCD), being with both high hardness and wear resistance and good thermal conductivity and strength, can meet the processing requirements of the wood cutting tools with long tool life, high processing efficiency and low total cost to some extent [1], but the grinding process of the PCD wood cutting tools is very difficult for its low grinding ratio (usually only $0.001-0.003$ ) [2,3] and low processing efficiency, 
especially for its complex geometry of the sawtooth. PCD circular saw blade working at high speed, which makes high noise and vibration as well as the temperature gradient on the blade caused by inhomogeneous cutting heat, has negative effect on the working smoothness and stability of the circular saw blade. Therefore, high damping coefficient and low thermal expansion coefficient of the base material [4] and the rational geometrical structure and parameters of the PCD sawtooth are required for the saw blade. The geometrical feature and structure parameters of the sawtooth not only affect the working stability of the circular saw blade, but also directly effect the lifetime and processing efficiency of the tools. Rationally design of the tool geometry parameters of the PCD cutters can improve the processing surface quality of the workpiece as well as wear resistance and lifetime of the tools, hence increasing the process efficiency and reducing producing costs. Evermore PCD wood cutting circular saw blade will be invalid usually while PCD sawtooth appears crack in point where the stress concentrated. The crack formation mainly depends on the maximum magnitude of the stress [5]. Therefore it is very important to study the stress concentration and deformation of the circular saw blade. This paper focuses on the research of stress distribution and deformation on PCD saw blades by use of ANSYS, which has great value on optimism designing of cutter parameters of PCD saw blades.

\section{THE EXPERIMENTAL DESIGN AND CALCULATING PROCEDURE}

\section{The selection principle and design of the sawtooth parameters}

The geometric parameters of the PCD sawtooth plays an important role in the cutting process. The machining quality and the tool life will be improved with the increasing rake angle, which will make the cutting force, wear and the cutting heat smaller at the same time, but the sawtooth will be broken or valid being impacted in the high speed cutting if the rake angle is too small. The larger rake angle will be selected when cutting the soft materials, and the smaller rake angle will be selected to improve the intensity of the sawtooth when cutting the hard materials.

The cutting force and wear of the tool will be decreased, therefore, the machining quality will be improved with the increasing rear angle. The smaller rear angle will be selected to prevent damage of the tool when machining some high hardness materials. But the role of these factors must be considered comprehensively when the designing of the structure of the sawtooth parameters, because the friction between flank surface and the workpiece and its capacity of the chip under cutting process will be affected by the rear angle. The purpose of the balance of the above selection is to improve the machining quality, increasing the cutting efficiency and lasting the tools life.

The saw blades will be treated as planes in which two parameters of rake angle and rear angle were considered in this simulation analysis, therefore, the different rake angle $\left(15^{\circ}, 20^{\circ}\right)$ and rear angle $\left(12^{\circ}, 15^{\circ}, 18^{\circ}\right)$ based on the practical using parameters of the PCD saw blade and their combinations were designed in this simulation experiment as showed in Table 1.

\section{Table 1. The structure parameter designing of PCD sawtooth of the circular saw blades}

\begin{tabular}{c|c|c|c|c|c|c}
\hline \multirow{2}{*}{ Parameters } & \multicolumn{7}{|c}{ Samples } \\
\cline { 2 - 7 } & 1 & 2 & 3 & 4 & 5 & 6 \\
\hline Rake angle $\gamma$, grad & 15 & 15 & 15 & 20 & 20 & 20 \\
Rear angle $\alpha$, grad & 12 & 15 & 18 & 12 & 15 & 18 \\
\hline
\end{tabular}




\section{Mechanical analysis of circular sawblade in cutting process}

Figure 1 shows the force analysis of PCD woodcutting circular saw blade under cutting process. The relationship between the number of saw teeth in cutting and cutting depth can be calculated from Fig. 1 as follows

$$
Z=\frac{R}{P} \arccos \left(1-\frac{a_{p}}{R}\right),
$$

where $Z$ is the number of teeth in cutting, $a_{p}$ is the cutting depth, $R$ is the radius of the saw blade, and $P$ is the tooth pitch.

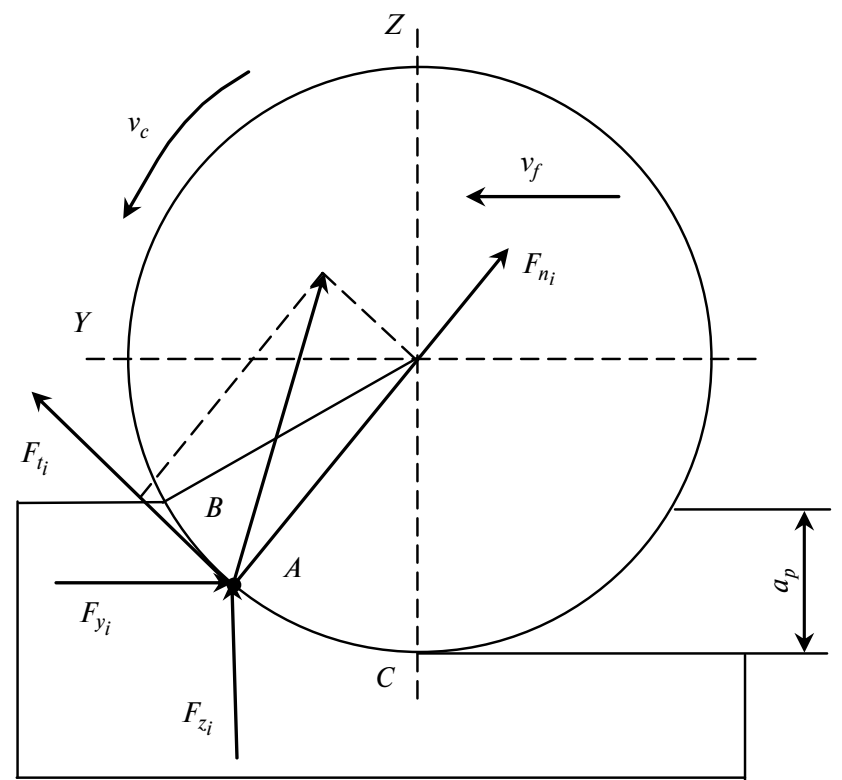

Fig. 1. The diagram of mechanical analysis of PCD saw blades under cutting process.

From Eq. (1) we can see that the greater the depth of cut, the more teeth involved in cutting. The cutting forces of the saw blade are the normal force $F_{n}$ and the sawing force $F_{t}$. The normal force $F_{n}$ is produced by the squeezing of the saw blade against the workpiece, it affects the cutting stability and wear resistance of the saw blade as well as the surface quality of the workpiece under cutting process. Sawing force $F_{t}$ is generated by the friction between the surface of the saw blade and the workpiece, it is the main cutting force of the saw blade and determines the cutting efficiency directly. The action area of sawing force $F_{t}$ and normal force $F_{n}$ is in the arc area $\mathrm{BC}$, where the actual cutting took place during the sawing process. Because of the difficulty of direct measurement of the cutting force $F_{t}$ and $F_{n}$, we divide the sawing force $F_{t}$ and the normal force $F_{n}$ into force $F_{y}$ and $F_{z}$ in the feed direction and perpendicular to the feed direction [7-8]. From the geometry relationship showed in Fig. 1, the following formula was obtained

$$
F_{y}=F_{n} \sin \theta-F_{t} \cos \theta ; F_{y}=F_{z} \cos \theta+F_{t} \sin \theta .
$$

\section{The finite element analysis method and procedure}

The properties of materials. The matrix material of the circular saw blade is $65 \mathrm{Mn}$ alloy steel, the saw tooth material of the circular saw blade is polycrystalline 
diamond compacts (PCD). The properties of the matrix and saw tooth materials was showing in Table 2 respectively.

\section{Table 2. The properties of matrix and saw tooth materials of PCD saw blades}

\begin{tabular}{c|cccc}
\hline Properties of materials & Density $\rho, \mathrm{kg} / \mathrm{m}^{3}$ & Elastic modulus $E, \mathrm{~N} / \mathrm{m}^{2}$ & Poisson ratio $\mu$ \\
\hline $65 \mathrm{Mn}$ & 7800 & $2.0 \cdot 10^{11}$ & 0.30 \\
$\mathrm{PCD}$ & 3500 & $8.5 \cdot 10^{11}$ & 0.07 \\
\hline
\end{tabular}

The structure parameters of the saw blade. The PCD saw teeth is welded on the matrix material of $65 \mathrm{Mn}$ steel in the circular saw blade. Without considering the strength of the welding, the circular saw blade matrix and the sawtooth is considered to be a rigid material with both materials. The diameter of the PCD circular saw blade is $300 \mathrm{~mm}$ with 40 teeth. The structure and parameters are selected according to the actual PCD circular saw blade as shown in Table 3.

\section{Table 3. Structure parameters $(\mathrm{mm})$ of matrix and sawtooth of PCD saw blades}

\begin{tabular}{c|c|c|c|c|c}
\hline \multicolumn{3}{c|}{ Matrix } & \multicolumn{3}{c}{ Saw tooth } \\
\hline $\begin{array}{c}\text { outer } \\
\text { diameter }\end{array}$ & $\begin{array}{c}\text { inner } \\
\text { diameter }\end{array}$ & thickness & length & thickness & height \\
\hline 300 & 60 & 2.5 & 4 & 4 & 2 \\
\hline
\end{tabular}

The modelling. The plane stress method was considered to analyze the PCD circular saw blades, and the PLANE 183 was selected as the finite element type. Considering the denser the meshing is, the more accurate of the calculation results and the smaller error will be, but the calculation time will be longer as well, we choose the triangle grid according to the actual sawing conditions, and make the calculation results close as possible to the actual cutting conditions.

The numerical calculation procedure. The numerical calculation procedure is first making conditional constraint to the calculating model before calculating, then loading the load, at last calculating, outputting and analyzing the results.

1. The loading constraints.

The uniform rotation around the axial direction under the drive of motor was the only movement and all other directions were fixed, so the inner hole of the saw blades will be treated as full constraints in the cutting process.

2. The loading stress and solution.

It is indicated that the tangential force $F_{t}$ was $257 \mathrm{~N}$ and force $F_{n}=59 \mathrm{~N}$ when the cutting depth was $10 \mathrm{~mm}$ and the rotation speed was $1000 \mathrm{r} / \mathrm{min}$ [9]. The whole stress was regarded as acting on the two sawteeth, which participating the cutting process, the loading area was in the upside and flank of the sawtooth [9]. The area of flank stress $A_{t}$ was the height times thickness and the area of upside stress was the length times thickness of the sawtooth.

Therefore the loading stress of the sawtooth can be obtained through the following calculations

$$
q_{t}=\frac{1}{2} F_{t} / A_{t}, q_{t}=16062500 \mathrm{~Pa} ; q_{n}=\frac{1}{2} F_{n} / A_{n}, q_{n}=1843750 \mathrm{~Pa},
$$

where $q_{t}$ and $q_{n}$ were loading stresses of the sawtooth in rotation and radial direction of the sawtooth separately. 


\section{The outputting the simulating results.}

After the uniform stress of the sawtooth and full constraints of inner hole of the saw blade were loaded as the bounding conditions, the cutting stress and deformation of the saw blade were analyzed by the ANSYS, then the cutting stress and deformation clouds image of the saw blade with different angles were outputted as showing in Fig. 2 and Fig. 4-5 separately, at last the maximum principal stresses and maximum displacement of the PCD saw blades were listed in Table 4 and Table 5 separately according to the simulation results.

\section{SIMULATION EXPERIMENT RESULTS AND DISCUSSION}

\section{The numerical calculation of the stress}

The simulating atlas cloud of the 1st principal stress and 3rd principal stress of PCD wood cutting circular saw blades with six group angles were shown in Fig. 2, and the calculating maximum of the 1st principal stress and 3rd principal stress of PCD wood cutting circular saw blades with six group angles was shown in Table 4.

The main simulating results of the 1 st principal stress and 3rd principal stress clouds of the PCD saw blades with rake angle $\gamma=15^{\circ}$ and rear angle $\alpha=12^{\circ}$ are shown in Figs. 3, $a$ and 3, $c$ separately, and Fig. 3, $b$ is the enlarged stress clouds of Fig. 3, $a$ in the root area of the sawtooth and near the silencing groove of the saw blade. From Fig. 3 it can be seen clearly that the main stress concentration took place at the sawtooth back along the upside groove of matrix, under the root of the sawtooth near the silencing groove, and at the matrix periphery of the inner hole of the saw blades. The 1st maximum principal stress was at the sawtooth back in the upside groove of matrix, and the 3rd maximum principal stress was under the root of sawtooth near the silencing groove of the matrix.

\section{Table 4. The simulation results of principal stress (MPa) of PCD saw blade with different cutting angles}

\begin{tabular}{c|c|c|c|c|c|c|c|c|c}
\hline $\begin{array}{c}\text { Sam- } \\
\text { ples }\end{array}$ & Parameters & $\begin{array}{c}\text { Posi- } \\
\text { tion }\end{array}$ & $\sigma_{1 \max }$ & $\sigma_{3 \max }$ & $\begin{array}{c}\sigma_{1 \max }- \\
\sigma_{3 \max }\end{array}$ & $\begin{array}{c}\text { Posi- } \\
\text { tion }\end{array}$ & $\sigma_{1 \max }$ & $\sigma_{3 \max }$ & $\begin{array}{c}\sigma_{1 \max } \\
\sigma_{3 \max }\end{array}$ \\
\hline 1 & $\gamma=15^{\circ}, \alpha=12^{\circ}$ & & 58.2 & 0 & 58.2 & & 0 & -36.6 & 36.6 \\
2 & $\gamma=15^{\circ}, \alpha=15^{\circ}$ & & 58.9 & 0 & 58.9 & & 0 & -38.5 & 38.5 \\
3 & $\gamma=15^{\circ}, \alpha=18^{\circ}$ & root & 59.8 & 0 & 59.8 & back & 0 & -36.8 & 36.8 \\
4 & $\gamma=20^{\circ}, \alpha=12^{\circ}$ & area & 75.6 & 0 & 75.6 & area & 0 & -40.9 & 40.9 \\
5 & $\gamma=20^{\circ}, \alpha=15^{\circ}$ & & 65.7 & 0 & 65.7 & & 0 & -34.9 & 34.9 \\
6 & $\gamma=20^{\circ}, \alpha=18^{\circ}$ & & 65.1 & 0 & 65.1 & & 0 & -39.2 & 39.2 \\
\hline
\end{tabular}

According to the third strength theory, $\sigma_{1}-\sigma_{1} \leq[\sigma]$, the maximum shear stress of the saw blade suffered in cutting process should be in the range of safety allowable stress. That is, the first maximum principal stress minus the third maximum principal stress should be less than the safety allowable stress of the matrix and PCD materials. It is known that the allowable shearing stress of matrix materials $65 \mathrm{Mn}$ was $270 \mathrm{MPa}$. The calculation value of $\left|\sigma_{1 \max }-\sigma_{3 \max }\right|$ of the six group parameters of the saw blades in cutting process was shown in Table 4. It is shown that the calculation value of $\left|\sigma_{1 \max }-\sigma_{3 \max }\right|$ are all much less than the safety allowable stress value of the matrix, that is $\left|\sigma_{1 \max }-\sigma_{3 \max }\right|<270 \mathrm{MPa}$. So it is indicated that the PCD saw blades designed in this experiment was all safety under the simulating sawing conditions. 


\begin{tabular}{|c|c|c|c|c|c|}
\hline \multicolumn{6}{|c|}{$\gamma=15^{\circ}$} \\
\hline \multicolumn{3}{|c|}{$\alpha$} & \multicolumn{3}{|c|}{$\alpha$} \\
\hline $12^{\circ}$ & $15^{\circ}$ & $18^{\circ}$ & $12^{\circ}$ & $15^{\circ}$ & $18^{\circ}$ \\
\hline \multicolumn{3}{|c|}{$1 \mathrm{st} \times 10^{8}$} & \multicolumn{3}{|c|}{$3 \mathrm{nd} \times 10^{8}$} \\
\hline 0 & 0 & 0 & -.824 & -.867 & -.827 \\
\hline .0646 & .0654 & .0664 & -.733 & -.771 & -.735 \\
\hline .129 & .131 & .133 & -.641 & -.674 & -.644 \\
\hline .194 & .196 & .199 & -.550 & -.578 & -.552 \\
\hline .259 & .262 & .266 & -.458 & -.482 & -.460 \\
\hline .323 & .327 & .332 & -.366 & -.385 & -.368 \\
\hline .388 & .393 & .398 & -.275 & -.289 & -.276 \\
\hline .452 & .458 & .465 & -.183 & -.193 & -.184 \\
\hline .517 & .524 & .531 & -916 & -.0963 & -.0919 \\
\hline .582 & .589 & .598 & 0 & 0 & 0 \\
\hline \multicolumn{6}{|c|}{$\gamma=20^{\circ}$} \\
\hline 0 & 0 & 0 & -.920 & -.785 & -.883 \\
\hline .0840 & .0730 & .0723 & -.818 & -.698 & -.785 \\
\hline .168 & .146 & .145 & -.716 & -.610 & -.687 \\
\hline .252 & .219 & .217 & -.614 & -.523 & -.588 \\
\hline .336 & .292 & .289 & -.511 & -.436 & -.490 \\
\hline .420 & .365 & .361 & -.409 & -.349 & -.392 \\
\hline .504 & .438 & .434 & -.307 & -.262 & -.294 \\
\hline .588 & .511 & .506 & -.205 & -.174 & -.196 \\
\hline .672 & .584 & .578 & -.102 & -.0872 & -.0981 \\
\hline .756 & .657 & .651 & 0 & 0 & 0 \\
\hline
\end{tabular}

Fig. 2. Stress cloud atlas of PCD wood saw blade with different tooth angles.

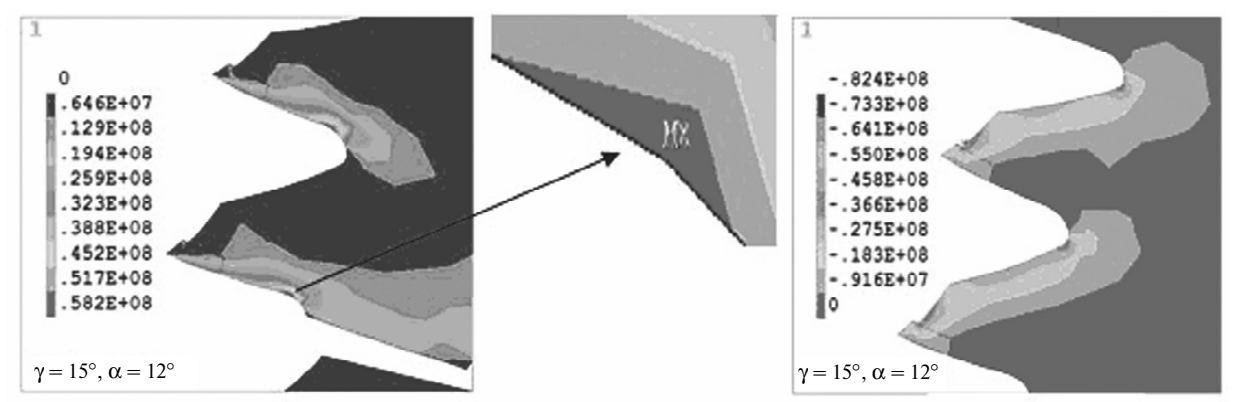

Fig. 3. Stress cloud atlas of the 1st principal stress $(a)$, maximum stress $(b)$ and 3rd principal stress $(c)$ of the PCD saw blade with rake angle $\gamma=15^{\circ}$ and rear angle $\alpha=12^{\circ}$. 


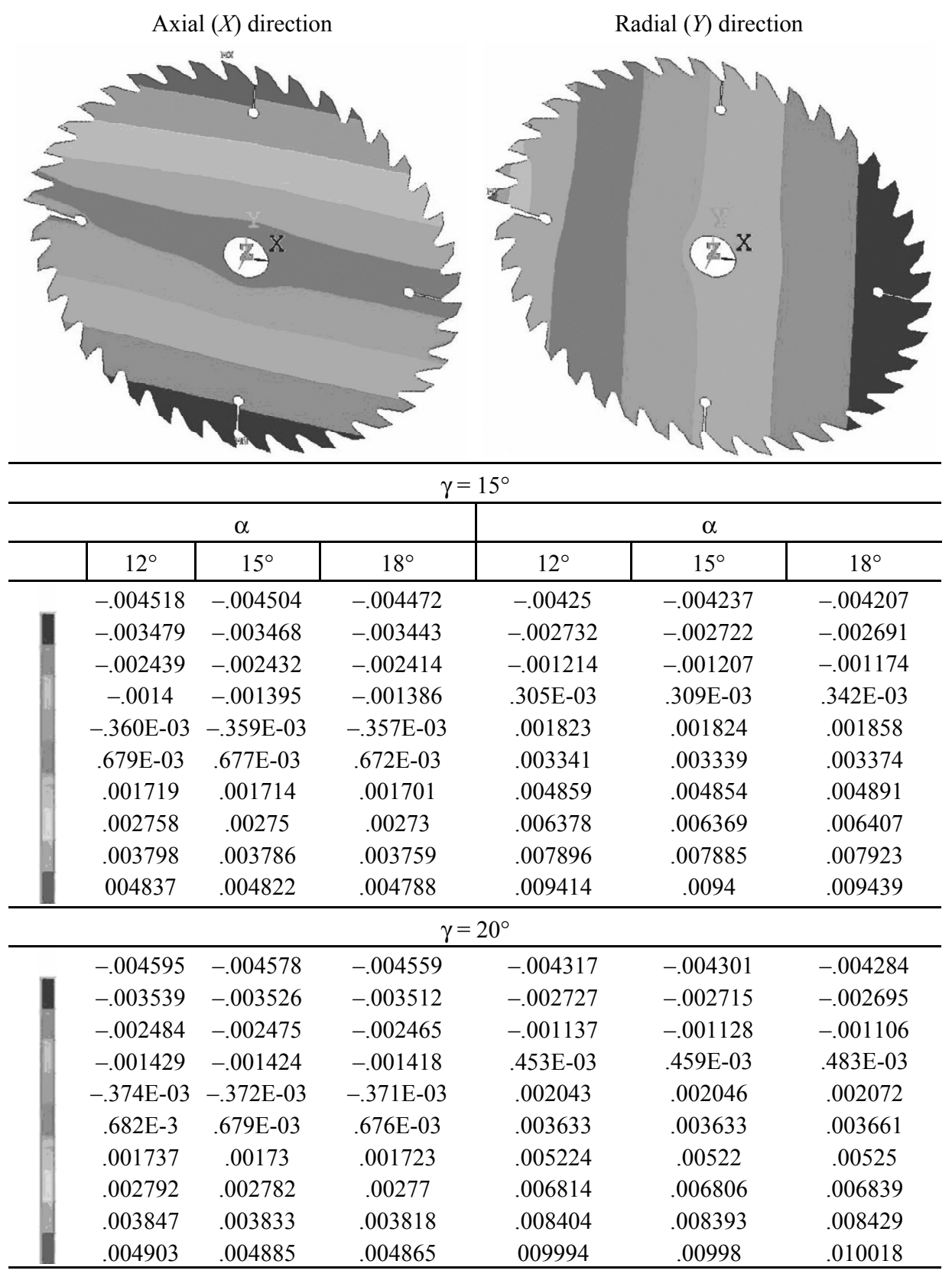

Fig. 4. Axial $(X)$ and radial $(Y)$ directions deformation simulating cloud atlas of PCD saw blade with different tooth angles.

From Table 4 it can be found that the third principal stress is zero as the first principal stress was maximum in the stress concentration area and vice versa, so the relative lower shear stress at the two stress concentration area of the saw tooth occurred meanwhile in sample No. 1 and No. 2, it indicates that the cutting force in these samples may be relative low, hence the cutting efficiency and the tool life of the PCD wood saw blades would be improved when the rake angle and rear angle were designed as $\gamma=15^{\circ}, \alpha=12^{\circ}$ and $\gamma=15^{\circ}, \alpha=15^{\circ}$, respectively. 


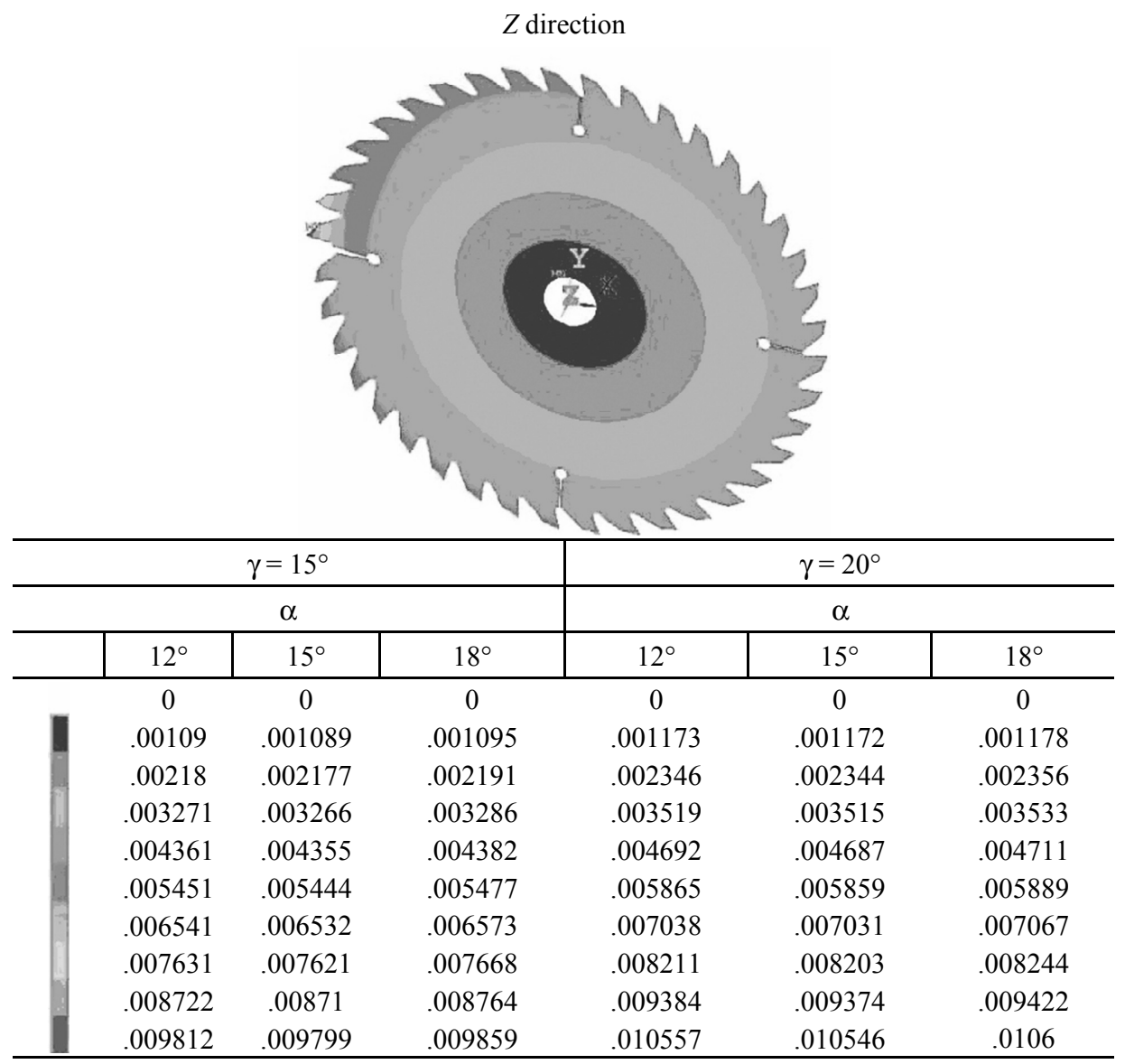

Fig. 5. Rotating $(Z)$ direction deformation simulating cloud atlas of PCD saw blade with different tooth angles.

\section{The numerical calculation of the deformation}

The axial direction $(X)$, radial direction $(Y)$ and rotation direction $(Z)$ simulating atlas cloud of PCD wood cutting circular saw blades with six group angles were shown in Fig. 4 and Fig. 5 separately, and the calculated $X, Y$ and $Z$ direction maximum displacement of PCD wood cutting circular saw blades with six group angles was shown in Table 5.

Table 5. The maximum displacement $(\mu \mathrm{m})$ of PCD saw blades calculated with different angles

\begin{tabular}{c|c|c|c|c}
\hline Samples & Parameters & X direction & $Y$ direction & $Z$ direction \\
\hline 1 & $\gamma=15^{\circ}, \quad \alpha=12^{\circ}$ & 4.837 & 9.414 & 9.812 \\
2 & $\gamma=15^{\circ}, \quad \alpha=15^{\circ}$ & 4.822 & 9.400 & 9.799 \\
3 & $\gamma=15, \quad \alpha=18^{\circ}$ & 4.788 & 9.439 & 9.859 \\
4 & $\gamma=20^{\circ}, \quad \alpha=12^{\circ}$ & 4.909 & 9.994 & 10.557 \\
5 & $\gamma=20^{\circ}, \quad \alpha=15^{\circ}$ & 4.885 & 9.980 & 10.546 \\
6 & $\gamma=20^{\circ}, \alpha=18^{\circ}$ & 4.865 & 10.018 & 10.600 \\
\hline
\end{tabular}


From Table 5 it can be seen that the maximum displacements of PCD saw blades in the axial direction $(X)$ decrease with the increasing rear angle, while the maximum displacements in radial direction $(Y)$ and rotation direction $(Z)$ first decrease then increase with the increasing rear angle. It can be found that the maximum displacements of PCD saw blades in all directions increase with the increase of the rake angle. The results indicate that the greatest rigidity and smallest deformation of the PCD saw blades would be obtained when the rear angle $\gamma$ was $15^{\circ}$. In fact the relative smaller deformation of saw blades indeed occurred in the sample No. 2 with the $15^{\circ}$ rake angle and rear angle.

\section{Optimism designing of the cutter parameters}

From the above simulation results, we can see that although the cutting stress of the PCD wood cutting circular saw blades was in a safety range with a big safety coefficient, but the machining surface quality of wood workpiece would be affected with the deformation in axial $(X)$ direction, especially the cutting stability and safety is related to the deformation in radial $(Y)$ direction. Therefore, the influence of the structure parameters on the cutting surface roughness and tool life is much more importan than that of the cutting force in this simulation experiment. From stress optimism designing of the cutter parameters, the relative lower shear stress at the two stress concentrations areas of the sawtooth can be obtained in sample No. 1 and No. 2, while from the view point of deformation optimism designing, the relative smaller displacement at the sawtooth can be obtained in sample No. 2. Therefore, the best comprehensive performance of the PCD saw blades would be achieved when the rake angle $\gamma$ and rear angle $\alpha$ are all be designed as $15^{\circ}$.

\section{CONCLUSIONS}

The following conclusions can be drawn by the simulation analysis of cutting force and deformation of the PCD wood cutting circular saw blades through the finite element method.

The main stress concentration took place at the back of PCD saw tooth along the upside groove of matrix and under the root of the saw tooth near the silencing groove. The maximum shear stress of the PCD saw blade in cutting process are all in a safety range with safety coefficient of about 3.5-4.0.

The maximum displacement of PCD saw blades in axial direction decrease with the increasing rear angle, but in radial and rotation direction first decrease then increase with the increasing rear angle, while the maximum displacement of PCD saw blades in all directions increase with the increase of rake angle.

The simulation results show that the best cutter parameters of the PCD circular saw blades are rake angle $\gamma=15^{\circ}$ and rear angle $\alpha=15^{\circ}$, in which the relative low stress of $58.9 \mathrm{MPa}$ and relative smaller displacement of $4.822 \mu \mathrm{m}$ can be achieved.

\section{ACKNOWLEDGEMENT}

The authors acknowledge the financial support from the Natural Science Joint Foundation of Beijing (No.L150012), National Natural Science Foundation of China (No. 50342017) and Doctoral Fund of the Ministry of Education (No. 20120023110016).

Параметри різия ріжучої пластини ичиркулярної пилки грають вирімальну роль в прочесі різання деревини, вони безпосередньо впливають на якість обробленої поверхні і термін служби інструменту. Аналіз моделюванням зусилля різання і деформації полікристалічних алмазів полотен циркулярної пилки з різними параметрами різия вико- 
наний з використанням методу скінченних елементів. Результати аналізу показують, щзо максимальні напруги зсуву полотна пилки з полікристалічними алмазами при різанні знаходяться в безпечному діапазоні з коефіцієнтом безпеки - 3,5-4,0 і максимальний зсув полотен пилки складає 4,8-4,9 в осьовому напрямку, 10 мм в радіальному та в напрямку обертання. Виявлено, що найкращуі параметри різия циркулярної пилки з полікристалічними алмазами - ие передній кут $\gamma=15^{\circ} i$ задній $\alpha=15^{\circ}$, при яких може бути досягнуто відносно низьке (58,9 МПа) зусилля і відносно малий (4,822 мкм) зсув.

Ключові слова: полікристалічний алмаз (PCD), циркулярна пилка для різання дерева, аналіз кінцевого елемента (ANSYS), параметри різия.

Параметры резиа режущей пластины цииркулярной пиль играют решаюшую роль в прочессе резания древесины, они непосредственно влияют на качество обработанной поверхности и срок службы инструмента. Анализ моделированием усилия резания и деформации поликристаллических алмазов полотен циркулярной пиль с различныли параметрами резца выполнен с использованием метода конечных элементов. Результать анализа показывают, что максимальные напряжения сдвига полотна пиль с поликристаллическими алмазами при резании находятся в безопасном диапазоне с коэффициентом безопасности - 3,5-4,0 и максимальный сдвиг полотен пиль составляет 4,8-4,9 в осевом направлении, 10 мм в радиальном и направлении вращения. Обнаружено, что лучшие параметры резца ииирклярной пиль с поликристаллическими алмазами - это передний угол $\gamma=15^{\circ}$ и задний $\alpha=15^{\circ}$, при которых могут быть достигнуты относительно низкое (58,9 МПа) усилие и относительно мальй (4,822 мкм) сдвиг.

Ключевые слова: поликристаллический алмаз (PCD), ичикулярная пила для резки дерева, анализ конечного элемента (ANSYS), параметры резца.

1. Bai Q.S., Yao Y.X., Chen S.D. Research and development of polycrystalline diamond wood working tools. Int. J. Refract. Met. Hard Mater. 2002. Vol. 20. P. 395-400.

2. Werner G., Enter M. Grinding ability of PCD. Ind. Diamond Rev. 1989. Vol. 1. P. 32-33.

3. Hua Hongyan, Sun Biao, Cao Weifei. Grinding characteristics of PCD and sharpening technology of PCD cutting tool. Tool Technology. 2006. Vol. 40, no. 7. P. 65-67.

4. Pei Jingyu, Guo Changning, Hu Dejin. The electrical discharge grinding of polycrystalline diamond. J. Shanghai Jiaotong University. 2006. Vol. 40, no. 10. P. 1679-1683.

5. Cao Pingxiang. Application of thin kerf tungsten carbide saw blades. Wood Proc. Machinery. 2003. Vol. 6. P. 9-12.

6. Cao Pingxiang. Application, tooth shape and tooth angle of TCT circular saw blade. China Forestry Machinery Association Professional Committee of Forestry and woodworking tool woodworking tools, 2005. National Seminar on Production and Application of Technology. 2005. P. 57-80.

7. Qiu Jun, Huang Wei, Gao Junyong et al. Thermal stress analysis for dry cutting circular saw blade. Diamond Abrasives Eng. 2006. Vol. 3. P. 20-23.

8. Qiu Jun, He Zhijian, Xiang Lin. Thermal and rotary stresses coupled-field analysis for dry cutting circular saw blade. Stone. 2007. Vol. 6. P. 8-12.

9. Li Zhiguo. Research on the mechanics performance of diamond saw blade with special structure [D]. Guangxi: Guangxi University, 2002.

10. Zhou Ning. ANSYS mechanical engineering application examples [M]. Beijing: China Water Power Press, 2006.

11. Hu Yingning, Wang Chengyong et al. Characteristic analysis of base \& saw tooth structures of diamond saw blades (1), Tool Eng. 2001. Vol. 35, no. 7. P. 21-25.

12. Hu Yingning, Wang Chengyong et al. Characteristic analysis of base \& saw tooth structures of diamond saw blades (2). Tool Eng. 2001. Vol. 35, no. 8. P. 10-15. 